\title{
RISIKO KURANG ENERGI KRONIS (KEK) PADA IBU HAMIL DI INDONESIA
}

\author{
Sandjaja ${ }^{1}$ \\ ${ }^{1}$ Pusat Penelitian dan Pengembangan Gizi dan Makanan, Depkes RI
}

\section{ABSTRACT \\ CHRONIC ENERGY DEFICIENCY AMONG PREGNANT WOMEN IN INDONESIA}

\begin{abstract}
Maternal mid-upper arm circumference (MUAC) is a potential indicator of maternal nutritional status. It can serve as a predictor of low birth weight and other health related indicators. It is used in Indonesia to select woman of reproductive age and pregnant woman for nutrition intervention. However, there are few studies in Indonesia to examine risk factors associated with low MUAC. The objective of the study is to determine characteristics of areas, family, pregnant woman, and morbidity associated with low MUAC $(<23.5 \mathrm{Cm})$, as a predictor of chronic energy deficiency. Data used for the analysis is Riskesdas (Baseline Health Research) 2007. A total of 8187 pregnant women were used for the analysis. The result showed that the prevalence of low MUAC in Indonesia was $21.6 \%$, varied from $11.8 \%$ in Riau to $32.4 \%$ in East Nusa Tenggara. The prevalence is higher in rural than that in urban areas. The result also showed that high prevalence of low MUAC is associated with family characteristics (pregnant woman as dependent in the family, smaller and bigger household members, and poor quintiles of expenditure per capita). There was a negative association between the prevalence of low MUAC with age, education attainment, and height of mother. High prevalence of low MUAC was found for single mother, jobless, farmer, unskilled labor. There was no clear difference between low MUAC and morbidity or out-patient attendance in different type of health facilities.
\end{abstract}

Keywords: pregnant woman, upper-arm circumference

\section{PENDAHULUAN}

ingkaran lengan atas (LILA) sudah digunakan secara umum di Indonesia untuk mengidentifikasi ibu hamil risiko kurang energi kronis (KEK). Menurut Departemen Kesehatan ${ }^{1,2}$ batas ibu hamil yang disebut sebagai risiko KEK jika ukuran LILA kurang dari $23,5 \mathrm{Cm}$. Dalam pedoman Depkes tersebut disebutkan intervensi yang diperlukan untuk wanita usia subur (WUS) atau ibu hamil yang menderita risiko KEK.

Kurang energi kronis pada orang dewasa dapat diketahui dengan indeks massa tubuh (IMT) yang diukur dari perbandingan antara berat dan tinggi badan. Jika IMT kurang dari 18,5 dikatakan sebagai KEK. Akan tetapi pengukuran IMT memerlukan alat pengukur tinggi badan dan berat badan. Dibandingkan dengan pengukuran antropometri lain, pita LILA adalah alat yang sederhana dan praktis yang telah digunakan di lapangan untuk mengukur risiko KEK. Berbagai penelitian baik di Indonesia,4 maupun di luar negeri ${ }^{5}$ menunjukkan bahwa LILA merupakan salah prediktor yang cukup baik untuk menentukan risiko KEK. Selain itu LILA juga digunakan untuk prediktor terhadap risiko melahirkan bayi berat lahir rendah $(B B L R)^{3,4,5}$, kematian neonatal dini (kurang dari satu minggu setelah dilahirkan) $)^{6,7}$, status gizi bayi sampai dengan umur 9 tahun ${ }^{8}$.

Hubungan antara LILA dengan BBLR tersebut dapat dijelaskan karena kebutuhan energi untuk kehamilan yang normal perlu tambahan kira-kira 80.000 kalori selama masa kurang lebih 280 hari. Energi dalam protein ditaksir sebanyak $5180 \mathrm{kkal}$, dan lemak 36.337 Kkal. Agar energi ini bisa ditabung masih dibutuhkan tambahan energi sebanyak 26.244 Kkal, yang digunakan untuk mengubah energi yang terikat dalam makanan menjadi energi yang bisa 
dimetabolisir. Dengan demikian jumlah total energi yang harus tersedia selama kehamilan adalah 74.537 Kkal, dibulatkan menjadi 80.000 Kkal. Hal ini berarti perlu tambahan ekstra sebanyak kurang lebih 300 kalori setiap hari selama hamil ${ }^{9}$. Kebutuhan energi pada trimester I meningkat secara minimal. Kemudian sepanjang trimester II dan III kebutuhan energi terus meningkat sampai akhir kehamilan. Energi tambahan selama trimester II diperlukan untuk pemekaran jaringan ibu seperti penambahan volume darah, pertumbuhan uterus, dan payudara, serta penumpukan lemak. Selama trimester III energi tambahan digunakan untuk pertumbuhan janin dan plasenta.

Bila ibu mengalami risiko KEK selama hamil akan menimbulkan masalah, baik pada ibu maupun janin. KEK pada ibu hamil dapat menyebabkan resiko dan komplikasi pada ibu antara lain: anemia, pendarahan, berat badan ibu tidak bertambah secara normal, dan terkena penyakit infeksi. Pengaruh KEK terhadap proses persalinan dapat mengakibatkan persalinan sulit dan lama, persalinan sebelum waktunya (prematur), pendarahan setelah persalinan, serta persalinan dengan operasi cenderung meningkat. KEK ibu hamil dapat mempengaruhi proses pertumbuhan janin dan dapat menimbulkan keguguran, abortus, bayi lahir mati, kematian neonatal, cacat bawaan, anemia pada bayi, asfiksia intra partum (mati dalam kandungan), lahir dengan berat badan lahir rendah (BBLR). Bila BBLR bayi mempunyai resiko kematian, gizi kurang, gangguan pertumbuhan, dan gangguan perkembangan anak. Untuk mencegah resiko KEK pada ibu hamil sebelum kehamilan wanita usia subur sudah harus mempunyai gizi yang baik, misalnya dengan LILA tidak kurang dari $23,5 \mathrm{~cm}$. Apabila LILA ibu sebelum hamil kurang dari angka tersebut, sebaiknya kehamilan ditunda sehingga tidak beresiko melahirkan BBLR ${ }^{10}$.
Bila sudah banyak penelitian yang menunjukkan risiko KEK pada ibu hamil dan dampaknya terhadap ibu, janin, bayi lahir dan anaknya sampai umur 9 tahun, maupun risiko kematian, belum banyak studi yang mengemukakan faktor-faktor yang mempunyai asosiasi dengan terjadinya risiko KEK pada ibu hamil.

Tujuan penelitian ini adalah untuk mengetahui faktor-faktor pada ibu hamil, baik karakteristik daerah, keluarga, ibu hamil, dan penyakit yang mempunyai asosiasi dengan kejadian risiko KEK.

\section{BAHAN DAN CARA}

$$
\begin{aligned}
& \text { Penelitian ini menggunakan data } \\
& \text { sekunder Riset Kesehatan Dasar }
\end{aligned}
$$
(Riskesdas) 2007 ${ }^{11}$. Disain Riskesdas 2007 merupakan survei cross-sectional yang bersifat deskriptif. Populasi dalam Riskesdas 2007 adalah seluruh rumah tangga di seluruh pelosok Republik Indonesia. Sampel rumah tangga dan anggota rumah tangga dalam Riskesdas 2007 dirancang identik dengan daftar sampel rumah tangga dan anggota rumah tangga Susenas 2007. Berbagai ukuran sampling error termasuk didalamnya standard error, relative standard error, confidence interval, design effect dan jumlah sampel tertimbang menyertai setiap estimasi variabel.

Dari total sampel individu Riskesdas 2007, dibuat file baru hasil seleksi ibu hamil yang didapatkan dari kuesioner rumahtangga RKD07RT blok IV kolom 9 (Khusus ART perempuan 10-54 tahun, apakah sedang hamil?). Data individu yang tidak sesuai dengan kriteria hamil dikeluarkan. Data yang sudah diseleksi tersebut dilakukan merging dengan file individu RKD07.IND dan file Susenas BPS07.RT dengan menggunakan variabel kunci. Dengan proses merging tersebut didapatkan gabungan antara variabel yang menyangkut karakteristik rumahtangga dan individu.

Proses selanjutnya adalah melakukan verifikasi terhadap data dan variabel yang akan dianalisis. Nilai outliers dari variabel ukuran LILA, berat badan, tinggi badan, dan beberapa variabel kunci dikeluarkan dari 
proses analisis. Jumlah data bersih yang dianalisis sebanyak 8187 sampel ibu hamil.

Analisis univariate dilakukan pada setiap variabel yang dianalisis untuk mengetahui sebaran nilai variabel tersebut. Re-coding beberapa variabel dilakukan untuk melakukan pengelompokan (umur, pekerjaan, jumlah anggota rumahtangga, tinggi badan). Ukuran LILA dikelompokkan menjadi dua yaitu kurang dari $23,5 \mathrm{Cm}$ sebagai kelompok ibu hamil risiko KEK dan 23,5 Cm atau lebih sebagai kelompok bukan risiko KEK. Analisis bivariate berupa krostabulasi dilakukan untuk mengetahui perbedaan yang ada antara ibu hamil yang menderita risiko KEK pada berbagai variabel yang diuji. Uji yang dilakukan adalah uji Khikuadrat.

\section{HASIL}

Hasil analisis ibu hamil risiko KEK dapat dilihat pada Tabel 1 dengan jumlah sampel total untuk seluruh Indonesia sebanyak 8187 ibu hamil. Prevalensi ibu hamil risiko KEK di Indonesia sebesar 21,6 persen dengan prevalensi terendah terdapat di provinsi Riau $(11,8 \%)$ dan tertinggi di Nusa Tenggara Timur $(32,4 \%)$ dan Papua barat $(30,4 \%)$. Bila dilihat menurut wilayah, prevalensi ibu hamil risiko KEK umumnya lebih rendah di Indonesia bagian barat dibanding di Indonesia bagian Timur. Di wilayah Sumatra, prevalensi risiko KEK tertinggi di provinsi Bengkulu (25,6\%), sedangkan di wilayah Jawa Bali tertinggi di provinsi Banten $(27,8 \%)$.

Tabel 1

Ibu hamil risiko KEK menurut provinsi

\begin{tabular}{|c|c|c|c|c|c|}
\hline Provinsi & $n$ & $\%$ KEK & Provinsi & $\mathrm{n}$ & $\% \mathrm{KEK}$ \\
\hline NAD & 392 & 14,3 & Nusa Tenggara Barat & 209 & 19,1 \\
\hline Sumatera Utara & 512 & 14,5 & Nusa Tenggara Timur & 306 & 32,4 \\
\hline Sumatera Barat & 370 & 14,9 & Kalimantan Barat & 190 & 19,5 \\
\hline Riau & 212 & 11,8 & Kalimantan Tengah & 234 & 26,1 \\
\hline Jambi & 222 & 19,4 & Kalimantan Selatan & 246 & 22,8 \\
\hline Sumatera Selatan & 241 & 21,6 & Kalimantan Timur & 236 & 16,1 \\
\hline Bengkulu & 121 & 25,6 & Sulawesi Utara & 103 & 13,6 \\
\hline Lampung & 195 & 19,5 & Sulawesi Tengah & - & - \\
\hline Bangka Belitung & 140 & 15,0 & Sulawesi Selatan & 544 & 24,4 \\
\hline Kepulauan Riau & 146 & 16,4 & Sulawesi Tenggara & 262 & 27,5 \\
\hline DKI Jakarta & 133 & 19,5 & Gorontalo & 83 & 21,7 \\
\hline Jawa Barat & 548 & 19,3 & Sulawesi Barat & 103 & 16,5 \\
\hline Jawa Tengah & 683 & 27,2 & Maluku & 92 & 20,7 \\
\hline DI Yogyakarta & 51 & 17,6 & Maluku Utara & 113 & 18,6 \\
\hline Jawa Timur & 868 & 27,5 & Papua Barat & 112 & 30,4 \\
\hline Banten & 151 & 27,8 & Papua & 188 & 28,2 \\
\hline Bali & 181 & 18,2 & INDONESIA & 8187 & 21,6 \\
\hline
\end{tabular}

Bila dibandingkan dengan risiko KEK pada wanita usia subur (WUS) hasil Riskesdas $2007^{11}$, terlihat bahwa prevalensi risiko KEK pada ibu hamil di tingkat nasional $(21,6 \%)$ satu setengah kali lebih tinggi dibanding prevalensi risiko KEK pada WUS $(13,6 \%)$. Hal ini menunjukkan bahwa ibu hamil memasuki masa kehamilan dengan risiko lebih tinggi dibanding pada WUS pada umumnya. Antara prevalensi risiko KEK pada ibu hamil dan pada WUS di tingkat provinsi terdapat hubungan positif seperti terlihat pada Grafik 1. Analisis agregat tingkat provinsi pada Grafik 1 menunjukkan makin tinggi prevalensi risiko KEK pada WUS, makin tinggi prevalensi risiko KEK 
pada ibu hamil seperti terlihat pada trendline. Pola hubungan positif juga ditemukan antara prevalensi risiko KEK pada ibu hamil dan status gizi kurus pada orang dewasa yang diukur dengan indeks massa tubuh (IMT) seperti terlihat pada Grafik 2.

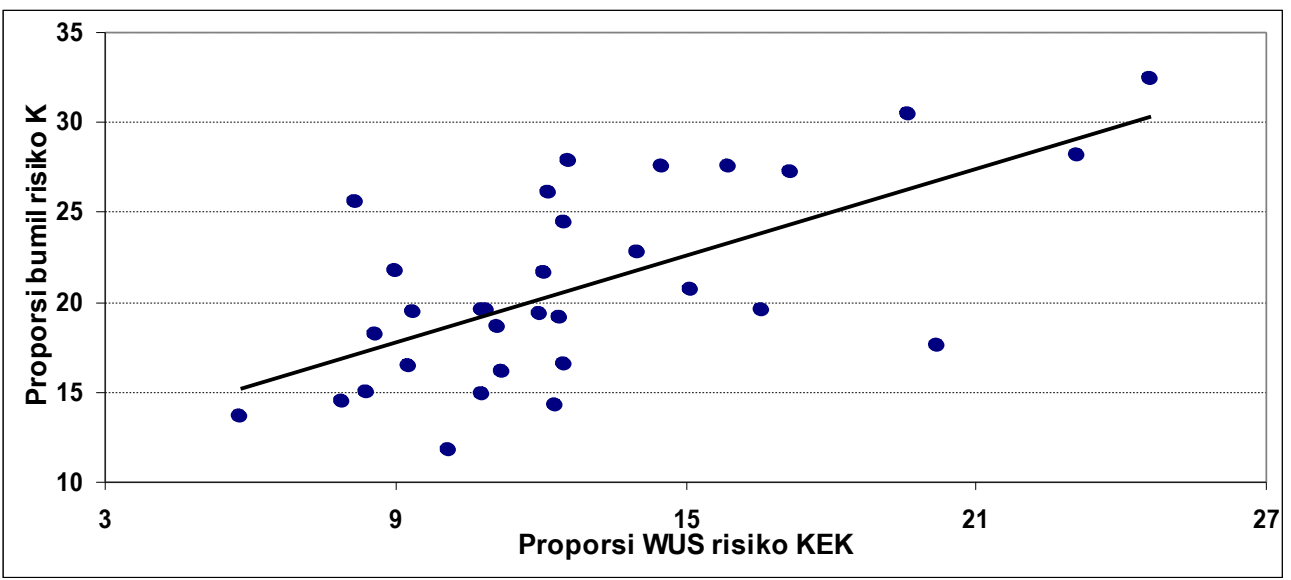

Grafik 1. Hubungan antara prevalensi risiko KEK pada WUS dan ibu hamil di tingkat agregat provinsi

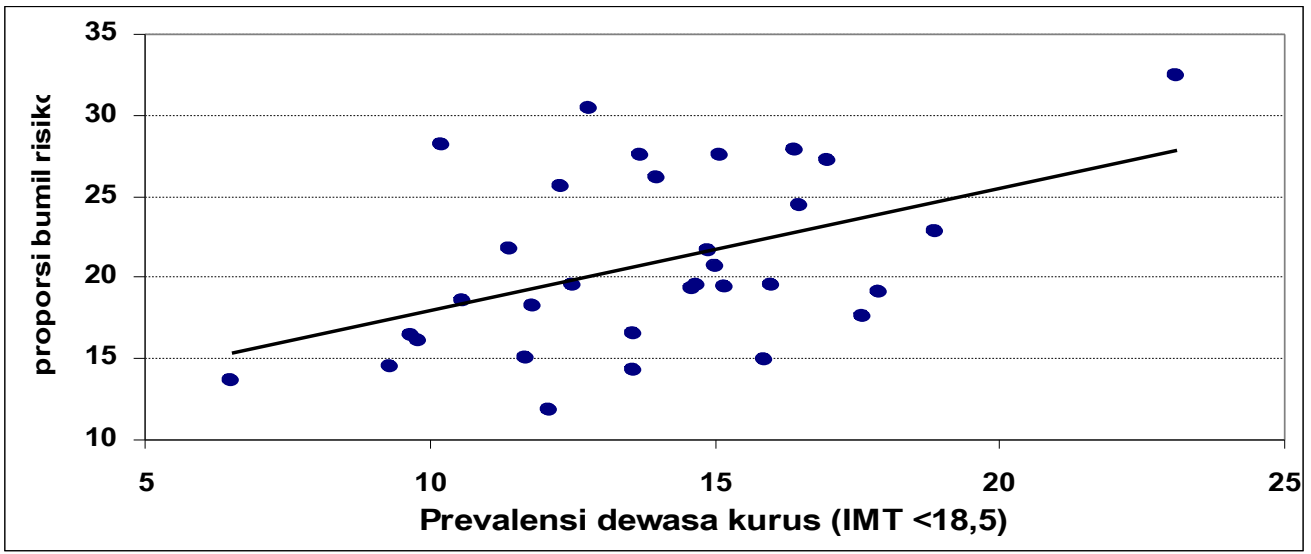

Grafik 2. Hubungan antara prevalensi kurus (IMT < 18,5) pada orang dewasa dan ibu hamil di tingkat agregat provinsi 


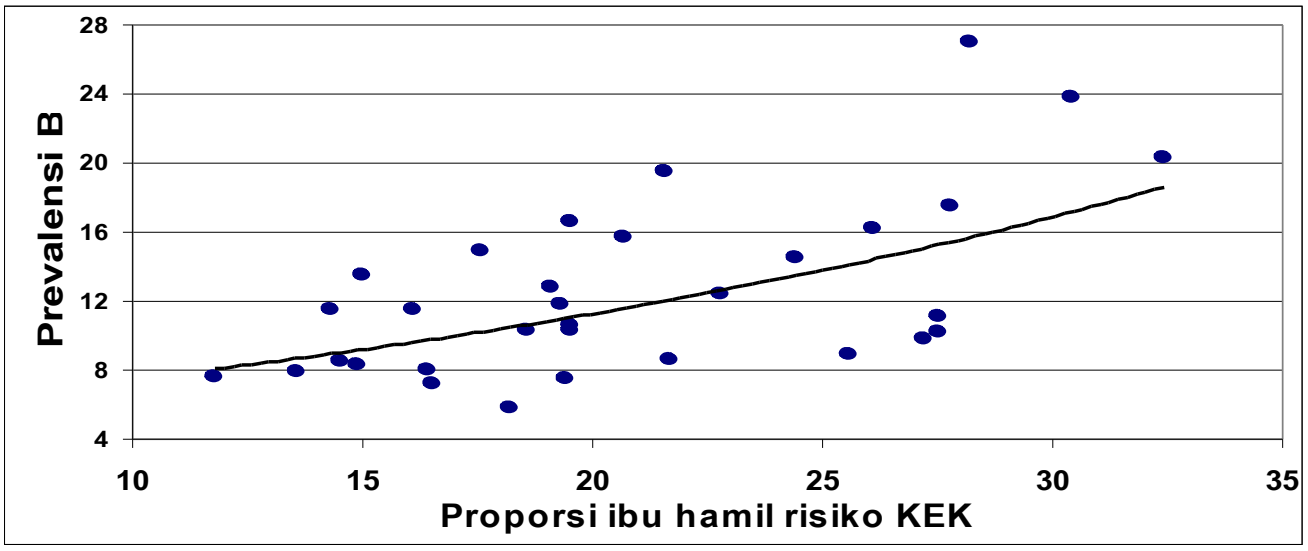

Grafik 3. Hubungan antara prevalensi risiko KEK pada ibu hamil dan prevalensi BBLR di tingkat agregat provinsi

Pada Grafik 3 terlihat hubungan antara prevalensi risiko KEK pada ibu hamil dan prevalensi BBLR di tingkat provinsi sesuai dengan hasil Riskesdas 200711. Terlihat pada grafik, terdapat korelasi positif antara risiko KEK pada ibu hamil dan BBLR. Analisis agregat di tingkat provinsi memperlihatkan makin tinggi prevalensi risiko KEK pada ibu hamil, makin tinggi prevalensi BBLR seperti terlihat pada garis trendline.
Pada Tabel 2 terlihat prevalensi risiko KEK pada ibu hamil menurut daerah tempat tinggal, yang menunjukkan perbedaan nyata prevalensi risiko KEK yang sedikit lebih tinggi di daerah perdesaan $(22,8 \%)$ dibanding di daerah perkotaan. Hal yang sama juga terjadi pada WUS hasil Riskesdas $2007^{11}$ yang lebih tinggi prevalensi risiko KEK di daerah perkotaan.

Tabel 2

Ibu hamil risiko KEK menurut tipe daerah

\begin{tabular}{|c|c|c|c|c|}
\hline \multirow{2}{*}{ Tipe daerah } & \multirow{2}{*}{$\mathrm{n}$} & \multicolumn{2}{|c|}{ Proporsi } & \multirow{2}{*}{ Uji Khi } \\
\hline & & KEK & Tidak KEK & \\
\hline Perkotaan & 3204 & 19,8 & 80,2 & $\begin{aligned} X^{2} & =10,680 \\
p & =0,001\end{aligned}$ \\
\hline Perdesaan & 4983 & 22,8 & 77,2 & \\
\hline
\end{tabular}

Tabel 3

Ibu hamil risiko KEK menurut karakteristik keluarga

\begin{tabular}{lrrrll}
\hline Karakteristik keluarga & $\mathrm{n}$ & \multicolumn{2}{c}{ Proporsi } & \multirow{2}{*}{ Uji Khi } \\
\hline Status dalam keluarga & 127 & 14,2 & 85,8 & $\mathrm{X}^{2}=151,306$ \\
Kepala keluarga & 5727 & 18,3 & 81,7 & $\mathrm{p}=0,000$ \\
Istri & 1485 & 31,8 & 68,2 & \\
Anak & 653 & 27,9 & 72,1 & \\
Menantu & 192 & 27,6 & 72,4 & \\
Lainnya & & & &
\end{tabular}

Jml anggota rumahtangga 


$<3$ orang
$3-4$ orang
$5-6$ orang
$7-8$ orang
$>8$ orang

Tkt pengeluaran per kapita

Kuintil 1

Kuintil 2

Kuintil 3

Kuintil 4

Kuintil 5

Bila Tabel 1 dan 2 memperlihatkan variasi ibu hamil risiko KEK menurut karakteristik daerah, pada Tabel 3 terlihat ibu hamil risiko KEK menurut karakteristik keluarga. Karakteristik keluarga yang dikumpulkan dalam Riskesdas 2007 dan dianalisis yaitu status ibu dalam keluarga, jumlah anggota rumahtangga, dan tingkat pengeluaran per kapita. Beberapa karakteristik keluarga lain yang dikumpulkan tidak diolah yaitu perumahan, air minum, sanitasi lingkungan, dan informasi tentang suami. Terlihat pada Tabel 3, ibu hamil mengalami risiko KEK tertinggi bila posisi ibu hamil adalah sebagai anak $(31,8 \%)$ dan menantu $(27,9 \%)$, sedangkan prevalensi terendah bila imu hamil sebagai kepala keluarga $(14,2 \%)$. Perbedaan posisi dalam kluarga tersebut memperlihatkan risiko signifikan lebih dari dua kali lipat bila ibu hamil sebagai anak dibanding ibu hamil sebagai kepala keluarga. Hal ini menunjukkan ibu hamil yang mandiri dalam penghasilan lebih baik status gizinya dibanding ibu hamil yang merupakan dependen kepada kepala keluarga.

Jumlah anggota rumahtangga walaupun memperlihatkan hasil uji signifikan, tetapi tidak ada perbedaan terlalu jauh dalam prevalensi risiko KEK pada ibu hamil. Pada keluarga dengan jumlah anggota kurang dari 3 orang yang dapat berarti keluarga muda, prevalensi risiko KEK 23,2 persen, turun pada keluarga dengan anggota rumahtangga 3-4 orang, dan naik kembali prevalensinya pada rumahtangga dengan anggota rumahtangga banyak, hingga mencapai prevalensi 25,9 persen jika anggota rumahtangga lebih dari 8 orang.

$\begin{array}{lll}23,2 & 76,8 & X^{2}=21,020 \\ 19,7 & 80,3 & p=0,000 \\ 22,7 & 77,3 & \\ 25,8 & 74,2 & \\ 25,9 & 74,1 & \\ 24,5 & 75,5 & X^{2}=20,176 \\ 23,3 & 76,7 & p=0,000 \\ 22,4 & 77,6 & \\ 20,4 & 79,6 & \\ 18,8 & 81,2 & \end{array}$

Tingkat pengeluaran per kapita sebagai cermin dari keadaan ekonomi rumahtangga juga mempunyai hubungan negatif yang signifikan dengan prevalensi risiko KEK. Makin tinggi pengeluaran per kapita, makin rendah prevalensi risiko KEK pada ibu hamil. Pada Tabel 3 terlihat prevalensi tertinggi risiko KEK terjadi pada kelompok kuintil-1 $(24,5 \%)$ yaitu kelompok termiskin dan menurun dengan meningkatnya pengeluaran per kapita sampai kelompok kuintil-5 yaitu kelompok terkaya hanya sebesar 18,8 persen. Pola yang hampir sama pada prevalensi risiko KEK juga terjadi pada hasil Riskesdas $2007^{11}$ pada WUS, prevalensinya 16,1 persen pada kuintil-1 dan menurun terus hingga menjadi 11,5 persen pada kuintil-5. Dari karakteristik rumahtangga tersebut, terlihat bahwa perhatian terhadap ibu hamil risiko KEK perlu ditujukan pada kelompok ibu hamil yang dalam keluarga berstatus sebagai anak atau menantu, jumlah anggota rumahtangga kecil atau besar, dan kelompok rumahtangga miskin.

Selain karakteristik daerah dan keluarga, Tabel 4 menunjukkan variasi prevalensi risiko KEK pada ibu hamil menurut karakteristik ibu sendiri. Karakteristik ibu tersebut ditinjau dari umur ibu, pendidikan ibu, status kawin, pekerjaan ibu, dan tinggi badan. Terlihat pada Tabel 4 terdapat hubungan negatif yang signifikan antara prevalensi risiko KEK pada ibu hamil dengan umur ibu. Pada kelompok umur ibu sangat muda, kurang dari 20 tahun, prevalensi risiko Kek paling tinggi yaitu 37,9 persen. Prevalensi tersebut menurun drastis menjadi 19,2 persen pada umur ibu 25-29 
tahun, hanya setengahnya dari kelompok umur muda, dan penurunan terus terjadi tetapi agak landai menjadi 14,3 persen pada kelompok umur ibu 40 tahun atau lebih.

Pola hubungan negatif yang signifikan juga terjadi antara tingkat pendidikan ibu dengan prevalensi risiko KEK pada ibu hamil. Makin tinggi pendidikan ibu, makin rendah prevalensi risiko KEK ibu hamil. Pada ibu hamil dengan pendidikan tidak sekolah, prevalensi risiko KEK 32,3 persen dan menurun pada kelompok pendidikan selanjutnya hingga hanya 19,4 persen pada ibu hamil dengan pendidikan tamat perguruan tinggi. Hubungan tersebut lebih nyata dibanding hasil Riskesdas $2007^{11}$ pada WUS, dimana prevalensi risiko KEK pada WUS yang tidak sekolah 15,8 persen dan menurun terus hingga pada WUS dengan pendidikan perguruan tinggi prevalensinya 12,5 persen.

Pada Tabel 4 juga terlihat perbedaan prevalensi risiko KEK yang nyata menurut status perkawinan. Pada ibu hamil dengan status menikah prevalensi risiko KEK 21,1 persen jauh lebih rendah dibanding status lainnya yaitu 30,5 persen. Perkawinan dengan status lainnya termasuk cerai hidup, cerai mati, dan belum kawin.

Pekerjaan juga berperan dalam risiko KEK pada ibu hamil. Prevalensi risiko KEK pada ibu hamil bila tidak bekerja $(31,9 \%)$ dan pekerjaan lainnya $(25,7 \%)$,dan petani, nelayan atau buruh (24,1\%), sedangkan prevalensi terendah bila pekerjaan ibu sebagai pegawai negri sipil, Polri, TNI atau pegawai BUMN (13,6\%).

Hubungan korelasi negatif selain terjadi pada tingkat pendidikan ibu dan risiko KEK, juga terjadi antara tinggi badan ibu dan risiko KEK. Makin tinggi ibu hamil, makin rendah prevalensi risiko KEK, sebaliknya makin pendek ibu makin tinggi risiko KEK. Pada ibu hamil dengan tinggi badan $165 \mathrm{Cm}$ atau lebih, risiko KEK hanya 12,8 persen, dan semakin tinggi risiko KEK dengan semakin pendek ibu. Pada ibu hamil dengan tinggi badan kurang dari $140 \mathrm{Cm}$ risiko KEK tiga kali lebih besar yaitu 37,4 persen. Dengan hasil ini terlihat bahwa karakteristik ibu yang perlu mendapat perhatian adalah ibu hamil umur kurang dari 20 tahun, tidak bersekolah, ibu tidak dalam ikatan pernikahan, ibu tidak bekerja atau pekerjaan yang menuntut aktivitas berat, dan ibu yang pendek.

Tabel 4

Ibu hamil risiko KEK menurut karakteristik ibu

\begin{tabular}{|c|c|c|c|c|}
\hline \multirow{2}{*}{ Karakteristik ibu } & \multirow[b]{2}{*}{$\mathrm{n}$} & \multicolumn{2}{|c|}{ Proporsi } & \multirow[b]{2}{*}{ Uji Khi } \\
\hline & & KEK & Bukan KEK & \\
\hline \multicolumn{5}{|l|}{ Umur ibu (tahun) } \\
\hline Kurang dari 20 & 762 & 37,9 & 62,1 & $X^{2}=251,265$ \\
\hline $20-24$ & 1916 & 28,3 & 71,7 & $p=0,000$ \\
\hline $25-29$ & 2358 & 19,2 & 80,8 & \\
\hline $30-34$ & 1722 & 16,3 & 83,7 & \\
\hline $35-39$ & 1040 & 14,5 & 85,5 & \\
\hline 40 atau lebih & 385 & 14,3 & 85,7 & \\
\hline \multicolumn{5}{|l|}{ Pendidikan ibu } \\
\hline Tidak sekolah & 235 & 32,3 & 67,7 & $X^{2}=32,362$ \\
\hline Tidak tamat SD & 903 & 22,8 & 77,2 & $p=0,000$ \\
\hline Tamat SD & 2384 & 23,2 & 76,8 & \\
\hline Tamat SMP & 1848 & 21,9 & 78,1 & \\
\hline Tamat SMA & 2182 & 18,8 & 81,2 & \\
\hline Tamat PT & 624 & 19,4 & 80,6 & \\
\hline \multicolumn{5}{|l|}{ Status kawin } \\
\hline Kawin & 7710 & 21,1 & 78,9 & $X^{2}=23,426$ \\
\hline
\end{tabular}




\begin{tabular}{|c|c|c|c|c|}
\hline & & & & \\
\hline \multicolumn{5}{|l|}{$\begin{array}{c}\text { Lainnya } \\
\text { Pekeriaan }\end{array}$} \\
\hline & & & & \\
\hline Tidak bekerja & 508 & 31,9 & 68,1 & \multirow{6}{*}{$\begin{array}{l}X^{2}=58,530 \\
p=0,000\end{array}$} \\
\hline Ibu rumahtangga & 4900 & 20,8 & 79,2 & \\
\hline PNS/TNI/Polri/BUMN & 257 & 13,6 & 86,4 & \\
\hline Wiraswasta & 939 & 18,0 & 82,0 & \\
\hline Petani/Nelayan/Buruh & 1207 & 24,1 & 75,9 & \\
\hline Lainnya & 374 & 25,7 & 74,3 & \\
\hline \multicolumn{5}{|l|}{ Tinggi badan ibu $(\mathrm{Cm})$} \\
\hline$<140,0$ & 123 & 37,4 & 62,6 & \multirow{7}{*}{$\begin{array}{l}X^{2}=193,963 \\
p=0,000\end{array}$} \\
\hline $140-144,9$ & 605 & 36,2 & 63,8 & \\
\hline $145-149,9$ & 1801 & 25,5 & 74,5 & \\
\hline $150-154,9$ & 2807 & 20,9 & 79,1 & \\
\hline $155-155,9$ & 2052 & 17,2 & 82,8 & \\
\hline $160-164,9$ & 627 & 14,0 & 86,0 & \\
\hline$>=165,0$ & 172 & 12,8 & 87,2 & \\
\hline
\end{tabular}

Tabel 5

Ibu hamil risiko KEK menurut karakteristik penyakit dan pengobatan

\begin{tabular}{|c|c|c|c|c|}
\hline \multirow{2}{*}{$\begin{array}{c}\text { Karakteristik penyakit } \\
\text { dan pengobatan }\end{array}$} & \multirow{2}{*}{$\mathrm{n}$} & \multicolumn{2}{|c|}{ Proporsi } & \multirow{2}{*}{ Uji Khi } \\
\hline & & KEK & Bukan KEK & \\
\hline \multicolumn{5}{|l|}{ Sakit ISPA 1 bulan terakhir } \\
\hline Ya & 620 & 23,1 & 76,9 & $X^{2}=0,792$ \\
\hline Tidak & 7565 & 21,5 & 78,5 & $p=0,389$ \\
\hline \multicolumn{5}{|l|}{ Sakit diare 1 bulan terakhir } \\
\hline Ya & 570 & 24,7 & 75,3 & $X^{2}=3,459$ \\
\hline Tidak & 7613 & 21,4 & 78,6 & $p=0,063$ \\
\hline \multicolumn{5}{|l|}{ Sakit TB paru 1 tahn terakhir } \\
\hline $\mathrm{Ya}$ & 65 & 30,8 & 69,2 & $X^{2}=3,213$ \\
\hline Tidak & 8120 & 21,6 & 78,4 & $p=0,073$ \\
\hline \multicolumn{5}{|c|}{$\begin{array}{l}\text { Tempat berobat rawat jalan } 1 \\
\text { tahun terakhir }\end{array}$} \\
\hline Rumah sakit & 444 & 20,0 & 80,0 & $X^{2}=15,000$ \\
\hline Puskesmas & 1606 & 24,8 & 75,2 & $p=0,005$ \\
\hline Praktek nakes & 2040 & 21,1 & 78,9 & \\
\hline Tidak sakit & 3940 & 21,0 & 79,0 & \\
\hline Lainnya & 155 & 15,5 & 84,5 & \\
\hline \multicolumn{2}{|c|}{$\begin{array}{l}\text { Pada Tabel } 5 \text { terlihat risiko KEK pada } \\
\text { ibu hamil menurut beberapa jenis penyakit } \\
\text { dan pengobatan rawat jalan. Terlihat bahwa } \\
\text { penyakit ISPA dan diare yang diderita ibu } \\
\text { hamil dalam satu bulan terakhir dan TB paru } \\
\text { dalam satu terakhir tidak banyak pengaruh- } \\
\text { nya terhadap risiko KEK. Walaupun preva- } \\
\text { lensi risiko KEK lebih tinggi pada ibu hamil } \\
\text { yang menderita ketiga penyakit tersebut, }\end{array}$} & \multicolumn{3}{|c|}{$\begin{array}{l}\text { tetapi perbedaan prevalensinya tidak terlihat } \\
\text { nyata. } \\
\text { Sebagian ibu hamil memanfaatkan } \\
\text { sarana pelayanan kesehatan rawat jalan } \\
\text { dalam satu tahun terakhir, tetapi sebagian } \\
\text { tidak memanfaatkan karena tidak mengalami } \\
\text { sakit atau alasan lain. Dilihat dari hal } \\
\text { tersebut, prevalensi risiko KEK pada ibu } \\
\text { hamil tidak banyak menunjukkan perbedaan }\end{array}$} \\
\hline
\end{tabular}


walaupun hasil uji statistik bermakna. Pada ibu hamil yang pernah memanfaatkan puskesmas untuk rawat jalan satu tahun terakhir menunjukkan prevalensi risiko KEK tertinggi yaitu 24,8 persen.

Analisis multivariate dengan logistic regression menunjukkan semua variabel yang diuji dalam hubungannya dengan prevalensi risiko KEK pada ibu hamil menghasilkan signifikan kecuali daerah tempat tinggai, status perkawinan, menderita sakit ISPA atau diare.

\section{BAHASAN}

Hasil analisis menunjukkan bahwa prevalensi risiko KEK pada ibu hamil di Indonesia sebesar 21,6 persen dengan variasi yang lebar antara 11.8 persen di Riau dan 32.4 persen in East Nusa Tenggara. Prevalensi risiko KEK tersebut lebih rendah bila dibandingkan dengan penelitian di 4 kabupaten pada tahun 1998 di Jawa Barat ${ }^{12}$ yang menemukan prevalensi risiko KEK pada ibu hamil sebesar 42,6 persen. Hasil penelitian tersebut juga menunjukkan bahwa KEK pada batas $23,5 \mathrm{Cm}$ belum merupakan resiko untuk melahirkan BBLR walaupun resiko relatifnya cukup tinggi. Tetapi dengan batas $23,0 \mathrm{Cm}$ risiko melahirkan bayi BBLR 2 kali lebih besar dibanding ibu hamil dengan LILA 23,0 Cm atau lebih. Penelitian lain di Bogor $^{3}$ menunjukkan dengan batas LILA $22,5 \mathrm{Cm}$ risiko ibu hamil melahirkan bayi BBLR 1,73 kali dan dengan batas LILA 23,7 $\mathrm{Cm}$ risiko bayi BBLR 1,84 kali lebih besar. Penelitian $\mathrm{Rah}^{8}$ di Bangladesh menunjukkan batas LILA 22,5 $\mathrm{Cm}$ risiko bayi BBLR 1,5 kali dibanding LILA di atas $22,5 \mathrm{Cm}$. Penelitian lain oleh Ricalde ${ }^{5}$ di Brazil tidak melakukan pembagian dalam dua kelompok menurut batas LILA tertentu, tetapi mencari hubungan korelasi antara usuran LILA dan berat lahir. Hasil penelitian tersebut menunjukkan korelasi positif $(r=0,4)$ antara ukuran LILA dan berat bayi. Makin besar usuran LILA makin berat badan lahir bayi.

Apabila penelitian sebelumnya tersebut mengaitkan antara risiko KEK pada ibu hamil dan BBLR di tingkat individu, analisis agregat tingkat provinsi pada penelitian ini menunjuk- kan pola yang serupa. Terdapat korelasi positif antara prevalensi risiko KEK pada WUS dan ibu hamil. Selain itu analisis agregat tingkat provinsi juga menunjukkan korelasi positif antara prevalensi risiko KEK pada ibu hamil dan prevalensi BBLR. Hal ini menunjukkan bahwa intervensi untuk meningkatkan status gizi pada ibu hamil bukan hanya berlaku untuk tingkat individu, tetapi juga untuk daerah dengan tingkat prevalensi risiko KEK yang tinggi. Oleh karena itu target program gizi dan kesehatan perlu diprioritaskan di daerah dengan prevalensi KEK yang tinggi. Di tingkat individu target program gizi dan kesehatan perlu diprioritaskan langsung pada ibu hamil yang penderita KEK. Hasil Riskesdas $2007^{11}$ menunjukkan prevalensi BBLR di Indonesia sebesar 11,5 persen.

Dengan demikian dapat diharapkan dampak lanjutan sebagai akibat penurunan BBLR yaitu berupa penurunan angka kematian bayi, terutama kematian neonatal dini. Hal ini dibuktikan dengan hasil penelitian $\mathrm{Katz}^{6}$ di Sarlahi, Nepal yang menunjukkan penurunan angka kematian neonatal dini $(\mathrm{OR}=0.88,95 \% \mathrm{Cl}=0.81$ 0.95) pada ibu hamil dengan LILA bukan risiko KEK. Penelitian lain oleh Christiana ${ }^{7}$ di daerah perdesaan di Nepal menunjukkan penurunan kematian neonatal (OR 0.76, 95\% Cl 0.67-0.87) dan post-neonatal (OR $0.64,95 \%$ Cl 0.41-0.99).

Analisis karakteristik daerah, rumah tangga, ibu hamil, pola penyakit dan pengalaman rawat jalan menunjukkan hampir semua variabel yang diuji memberikan hasil perbedaan signifikan tentang risiko KEK pada ibu hamil. Akan tetapi perlu untuk dicermati tingkat perbedaan signifikan dengan uji Khi-kuadrat dapat terjadi karena jumlah sampel ibu hamil yang besar. Perbedaan nyata prevalensi risiko KEK yang lebih tinggi pada ibu hamil di daerah perdesaan, posisi ibu hamil dalam keluarga masih ikut orangtua atau mertua yaitu sebagai anak atau menantu, jumlah anggota rumahtangga kecil (kurang dari 3 orang) atau besar, ibu hamil tidak dalam ikatan perkawinan, ibu yang bekerja sebagai petani, buruh tani, pekerjaan tidak menentu, atau 
tidak bekerja. Korelasi negatif yang signifikan terjadi antara kuintil pengeluaran per kapita, kelompok umur ibu, tingkat pendidikan ibu dan tinggi badan ibu. Semakin tinggi pengeluaran per kapita, semakin ibu bertambah umur, semakin tinggi tingkat pendidikan ibu, dan semakin tinggi badan ibu, maka semakin rendah prevalensi risiko KEK pada ibu hamil. Hubungan korelasi tersebut tidak hanya terjadi pada tingkat individu. Hasil analisis agregat tingkat provinsi menunjukkan korelasi positif antara prevalensi risiko KEK pada WUS, prevalensi orang dewasa kurus dengan IMT kurang dari 18,5, prevalensi BBLR dengan prevalensi risiko KEK pada ibu hamil.

Hasil tersebut memberikan makna bahwa untuk penajaman target intervensi gizi pada ibu hamil dengan risiko KEK lebih ditujukan untuk masyarakat di perdesaan, ibu hamil yang masih sebagai dependen dalam keluarga atau tanpa ikatan perkawinan, umur ibu masih muda di bawah 20 tahun, tingkat pendidikan ibu yang rendah, kelompok kuintil-1 atau masyarakat miskin, dan ibu hamil dengan tinggi badan kurang dari $145 \mathrm{Cm}$.

Ibu hamil merupakan kelompok rawan gizi. Risiko KEK pada ibu hamil mempunyai dampak yang cukup besar terhadap proses pertumbuhan janin dan anak yang akan dilahirkan. Bila ibu hamil mengalami risiko KEK, akibat yang akan ditimbulkan antara lain: keguguran, bayi lahir mati, kematian neonatal, cacat bawaan, anemia pada bayi, dan bayi lahir dengan BBLR.

Analisis data sekunder mengandung beberapa kekurangan yang perlu dicermati. Data yang ada tidak didesain khusus untuk melakukan analisis komprehensif faktorfaktor yang berhubungan dengan kejadian risiko KEK pada ibu hamil. Oleh karena itu sebagian variabel yang diduga berperan pada terjadinya KEK tidak ada dalam struktur data. Variabel yang diolah hanya variabel yang tersedia dalam data sekunder. Selain itu Riskesdas 2007 perlu dicermati beberapa hal yang mencakup non-random error antara lain: pembentukan kabupaten baru, blok sensus tidak terjangkau, rumah tangga tidak dijumpai, periode waktu pengumpulan data yang berbeda, estimasi tingkat provinsi untuk ibu hamil tidak bisa berlaku untuk semua indikator. Khusus untuk lima provinsi (Papua, Papua Barat, Maluku, Maluku Utara dan NTT) pelaksanaan pengumpulan data baru dilaksanakan pada bulan AgustusSeptember 2008, sementara 28 provinsi lainnya telah selesai dilaksanakan pada tahun 2007 sehingga ada kemungkinan perbedaan.

\section{KESIMPULAN}

Prevalensi nasional risiko KEK pada ibu hamil sebesar 21,6 persen dengan variasi yang cukup lebar dengan prevalensi terendah 11,8 persen di provinsi Riau dan 32,4 persen di provinsi Nusa Tenggara Timur.

Analisis karakteristik daerah, rumah tangga, ibu hamil, pola penyakit dan pengalaman rawat jalan menunjukkan hampir semua variabel yang diuji memberikan hasil perbedaan signifikan tentang risiko KEK pada ibu hamil. Perbedaan nyata prevalensi risiko KEK yang lebih tinggi pada ibu hamil di daerah perdesaan, posisi ibu hamil dalam keluarga masih ikut orangtua atau mertua yaitu sebagai anak atau menantu, jumlah anggota rumahtangga kecil (kurang dari 3 orang) atau besar, ibu hamil tidak dalam ikatan perkawinan, ibu yang bekerja sebagai petani, buruh tani, pekerjaan tidak menentu, atau tidak bekerja. Korelasi negatif yang signifikan terjadi antara kuintil pengeluaran per kapita, kelompok umur ibu, tingkat pendidikan ibu dan tinggi badan ibu.

\section{RUJUKAN}

1. Indonesia. Departemen Kesehatan, Ditjen Pembinaan Kesehatan Masyarakat. Pedoman penggunaan alat ukur lingkaran lengan atas (LILA) pada wanita usia subur. Jakarta: Depkes, 1994.

2. Indonesia. Departemen Kesehatan, Ditjen Pembinaan Kesehatan Masyarakat. Petunjuk teknis penanganan rujukan wanita usia subur 
risiko kurang energi kronis di puskesmas. Jakarta: Depkes, 1994.

3. Husaini JK, Husaini MA, Musa MS. Keterbatasan penggunaan LILA dalam memonitor status gizi wanita hamil. Jakarta: Bulletin Penel Kesehatan, 2003, 35:14-24.

4. Manik, R. Pengaruh Sosio Demografi, Riwayat Persalinan dan Status Gizi Ibu terhadap Kejadian BBLR, Studi Kasus di RSIA Sri Ratu Medan. Skripsi, Medan: FKM-USU, 2000.

5. Ricalde $A E$, Velasquez-melandez $G$, Tanaka AC, de Siqueria AAR. Midupper arm circumference in pregnant women and its relation to birth weight. Rev Saude Publica, 1998, 32 (2).

6. Katz J, LeClerq SC, Christian P, Khatry SK, Shrestha SR, West Jr KP, Pradhan EK. Risk factors for early infant mortality in Sarlahi district, Nepal. Bul. WHO, 2003, 81: 717-725.

7. Christiana P, Katza J, Lee W., Kimbrough-Pradhanb E, Khatryc SK LeClerga SC, West Jr KP. Risk factors for pregnancy-related mortality: A prospective study in rural Nepal. Public Health, 2008, 122 (2): 161-172.

8. Rah $\mathrm{JH}$, et al. Circumference in Pregnancy as a Predictor of Low Birthweight. $8^{\text {th }}$ Commonwealth Congress on Diarrhoea and Malnutrition (CAPGAN) 2006: Scientific Session 13: Low Birthweight.

9. Nasution AH. Gizi untuk Kebutuhan Fisiologis Khusus. Terjemahan Jakarta: PT Gramedia, 1988.

10. Lubis Z. Status gizi ibu hamil serta pengaruhnya terhadap bayi yang dilahirkan. Bogor: Institut Pertanian Bogor, 2003.

11. Indonesia. Departemen Kesehatan, Badan Litbang Kesehatan. Laporan hasil Riset Kesehatan Dasar (Riskesdas) Indonesia - Tahun 2007. Jakarta: Badan Litbang Kesehatan, 2008.

12. Sarawati E, Sumarno I. Risiko ibu hamil kurang energi kronis (KEK) dan anemia untuk melahirkan bayi dengan berat badan lahir rendah (BBLR). Penel Gizi Makanan,1998, 21: 41-49. 